\title{
Biological Analysis of Blue Swimmer Crab (Portunus pelagicus) from Collectors in Lamongan, Tuban, Pasuruan, and Rembang, Java, Indonesia
}

\author{
Lini Murni ${ }^{1 *}$, Diana Arfiati ${ }^{2}$, Andi Kurniawan ${ }^{2}$, Yuni Kilawati ${ }^{2}$, Herwati Umi Subarijanti ${ }^{2}$, \\ Suliswanto², Muhammad Nafar Amani Syams², Agum Bayu Gumelar², \\ Alif Raditya Amirul Huda² \\ ${ }^{1}$ Master Program of Fisheries and Marine Sciences, Faculty of Fisheries and Marine Sciences, University of Brawijaya, \\ Malang, Indonesia \\ ${ }^{2}$ Faculty of Fisheries and Marine Sciences, University of Brawijaya, Malang, Indonesia
}

\begin{abstract}
Blue swimmer crab (Portunus pelagicus) can increase the country's incomes due to its high demand of export. This study aims to determine biological analysis on the population of blue swimmer crab in Lamongan, Tuban, Pasuruan, and Rembang. The sampling location was based on the fishing area and the method used survey method from collectors in each location. The blue swimmer crab's biological characteristics which observed are the correlation on wide of carapace and blue swimmer crab weight, sex ratio, and gonad maturity level. The results showed the correlation between the wide and weight of carapace in Lamongan (male: 113.80-122.99 mm and 87.98-121.60 g then female: 108.21-117.27 mm and 71.80-99.74 g), Tuban (male: $113.26-117.74 \mathrm{~mm}$ and 89.63-102.76 $\mathrm{g} \mathrm{g}$ then female: $114.36 \mathrm{~mm}$ and $106.51 \mathrm{~g}$ ), Pasuruan (male: $87.66-94.43 \mathrm{~mm}$ and $39.68-49.90 \mathrm{~g}$ then female: $101.94-110.89 \mathrm{~mm}$ and $66.98-82.89 \mathrm{~g}$ ), and Rembang (male: 120.30-126.69 mm and 93.53-118.43 g then female: 125.30-132.13 mm and 134.42-157.47 g); sex ratio (male: female) in Lamongan (1.4: 1), Tuban (1: 1.5), Pasuruan (2.8: 1), and Rembang (1: 1.46); and also gonad maturity level in Lamongan (dominant male at level III was $30.29 \%$, female at level II and III was $30.40 \%$ ), Tuban (dominant male at level II was 41.93\%, female at level III was 33.33\%), Pasuruan (dominant male at level III was $25.79 \%$, female at level III was $48.10 \%$ ), and Rembang (dominant male at level II was 32.35\%, female at level II was $33.33 \%$ ). These results indicate that the total of Portunus pelagicus which was being caught had fulfilled the standards rules by No.1/PERMEN-KP/2015. However, it requires continuous direct monitoring and counseling to maintain the stock of blue swimmer crab resources.
\end{abstract}

Keywords: Blue swimmer crab (Portunus pelagicus), gonad maturity level, sex ratio, wide and weight.

\section{INTRODUCTION}

Blue swimmer crab (Portunus pelagicus) is included as one of fishery commodities that has high economic value and becomes one of the primadonnas in the field of fisheries. Besides in the local market, the swimmer crabs can be one of the high levels and promising export commodities [1]. The request of Blue swimmer crab for every year is always increase makes fishery export commodity such as frozen meat without skin or processed meat in cans. Indonesia's export of blue swimmer crab in 2011 showed the high rate of 42,410 tons with \pm Rp. 978 billion rupiahs [2].

The blue swimmer crab is an active swimmer, but in passive conditions it will bury themselves into sediment; only part of eye and antena which are not covered. Male of blue swimmer crab ( $P$. pelagicus) has blue color whereas the female one

\footnotetext{
* Correspondence address:

Lini Murni

Email : linimurni@gmail.com

Address : Faculty of Fisheries and Marine Sciences, University of Brawijaya, Veteran Malang, Malang 65145 .
}

has a brown-greenish color and has smaller claws than male [3]. The blue swimmer crab has lifecycle through a phase of zoea, megalopa, and instar I for 14-19 days. The phase of zoea I and II passed for 3-4 days each, a phase of zoea III and IV passed for 2-3 days each, and megalopa phase for 3-4 days. After megalopa phase, blue swimmer crab can metamorphose into first instar phase [4].

Eggs and larvae of blue swimmer crab ( $P$. pelagicus) are planktonic. The eggs of blue swimmer crab can hatch for 15 days into larvae. The larvae of blue swimmer crab last for 26-45 days and located as far as $80 \mathrm{~km}$ in the coastal ocean. Before becoming young blue swimmer crab, it stays 6 weeks in loose waters and return to estuary area to grow and flourish then return to sea as adults and then lay eggs in the sea in summer of tropical waters or in spring of subtropical waters [5]. The intestines of blue swimmer crab captured in shallow sublittoral waters of Kunduchi Darussalam coast of Tanzania are estimated to be blue swimmer crabs, crustaceans, fish bones and other foods. The 
dominant food is the type of bivalve order of Mytiloida from Arcuatula arcuatula type [6].

However, the decline of blue swimmer crabs can be caused by nature of cannibalism, this often cases when molting makes their soft carapace and often preyed by other blue swimmer crabs as well as other predators [7]. It need guarantees on consistent availability and continuous of blue swimmer crab resources so that domestic and foreign market demand can be fulfilled.

One way to ensure the availability of blue swimmer crab resources is by maintaining the existing populations in nature by controlling the exploitation of blue swimmer crabs resources. However, the increasing of market demand for blue swimmer crab resources causes to a higher levels of exploitation in nature. Lack of knowledge levels of fisherman and enforcement of rules made by the government results in continuous catching regardless of size and timing of the catch. This matter, in the availability of blue swimmer crab stock is declining in nature. That is why it need a well designed program to maintain the availability of blue swimmer crab. One of them is by understanding the blue swimmer crab's biological characteristic for the fisherman. Therefore, the purpose of this research is to understand the correlation of wide of carapace and blue swimmer crab weight, sex ratio, and gonad maturity level caught by fisherman in Paciran Subdistrict (Lamongan Regency), Bancar Subdistrict (Tuban Regency), Kraton Subdistrict (Pasuruan Regency), Sluke Subdistrict (Rembang Regency), and the conformity of the rules applied by No.1/PERMENKP/2015 (Regulation of Ministry of Marine and Fisheries about Lobster, crabs, and blue swimmer crabs catching).

The blue swimmer crab ( $P$. pelagicus) has similar morphology with crabs. It has greater width and length of carapace [8]. The blue swimmer crab caught in coastal waters generally have wide range of $8-13 \mathrm{~cm}$ carapace lengths with an average weight of $\pm 100 \mathrm{~g}$ at depth of 20 $m$ with an average blue swimmer crab being obtained at $53.34 \mathrm{~g}$ with low weight of $30 \mathrm{~g}$ and maximum weight of $160 \mathrm{~g}$ [9]. The increased water depth, the weight of the captured blue swimmer crab is larger, but the number of tails obtained is not as much as the depth is relatively shallow [10]. The male blue swimmer crabs prefer to be in the waters with low salinity, thus spreading more in shallow area. This difference in gonad maturity can be due to several factors such as individual body condition and latitude [6].

\section{MATERIAL AND METHOD \\ Study Area}

This research was conducted from collectors which is the representative of blue swimmer crab catching area. Paciran Subdistrict, Lamongan geographical coordinates: $6^{\circ} 52^{\prime} 0^{\prime \prime}$ South, $112^{\circ} 20^{\prime} 0^{\prime \prime}$ East (Fig. 1); Bancar Subdistrict, Tuban $6^{\circ} 47^{\prime} 0^{\prime \prime}$ South, $111^{\circ} 46^{\prime} 0^{\prime \prime}$ East (Fig. 2); Kraton Subdistrict, Pasuruan $7^{\circ} 32^{\prime} 34^{\prime \prime}-8^{\circ} 30^{\prime} 20^{\prime \prime}$ South, $112^{\circ} 33^{\prime} 55^{\prime \prime}-113^{\circ} 30^{\prime} 37^{\prime \prime}$ East (Fig. 3); and Sluke Subdistrict, Rembang $6^{\circ} 30^{\prime}-7^{\circ} 6^{\prime}$ South, $111^{\circ} 00^{\prime}$ East as shown in Figure 4.

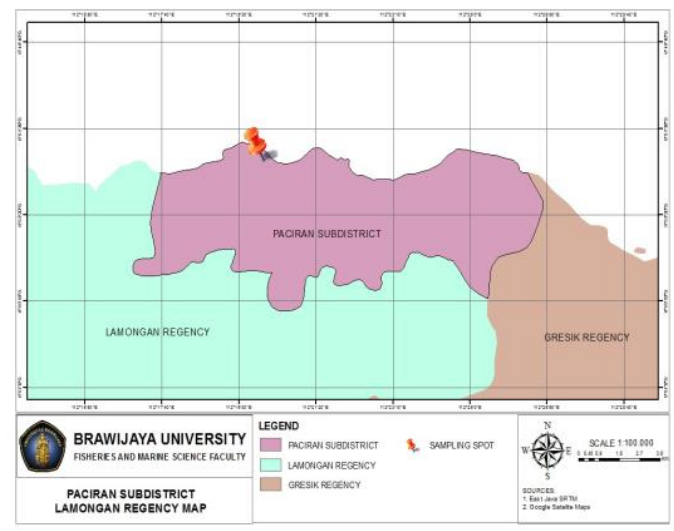

Figure 1. Paciran Subdistrict, Lamongan Regency

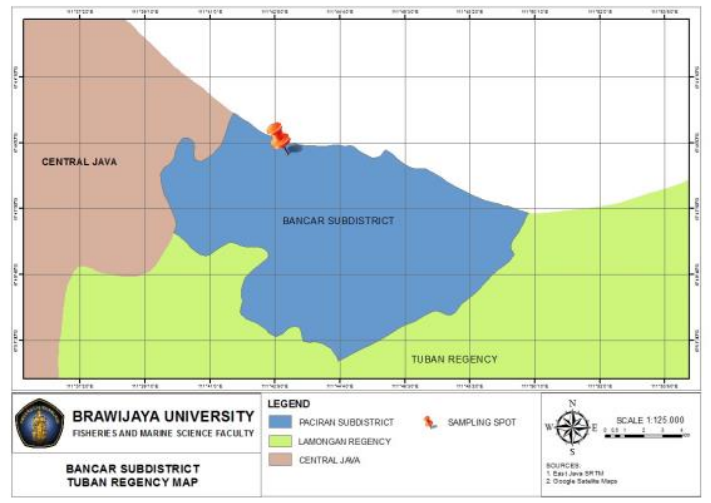

Figure 2. Bancar Subdistrict, Tuban Regency

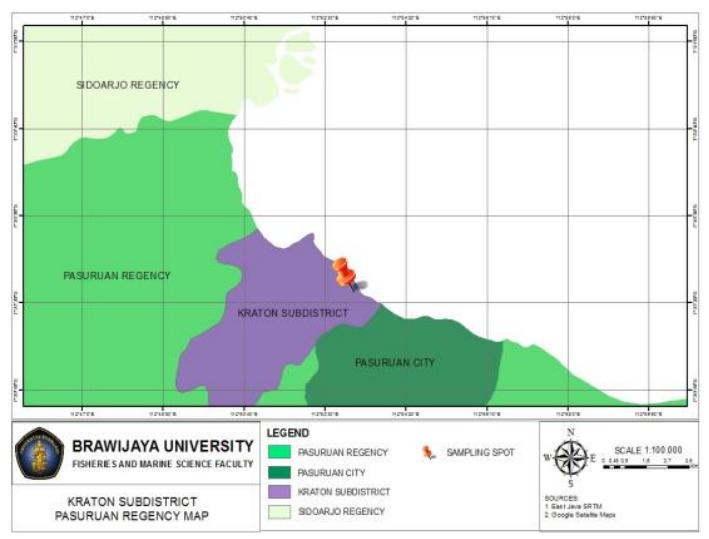

Figure 3. Kraton Subdistrict, Pasuruan Regency 


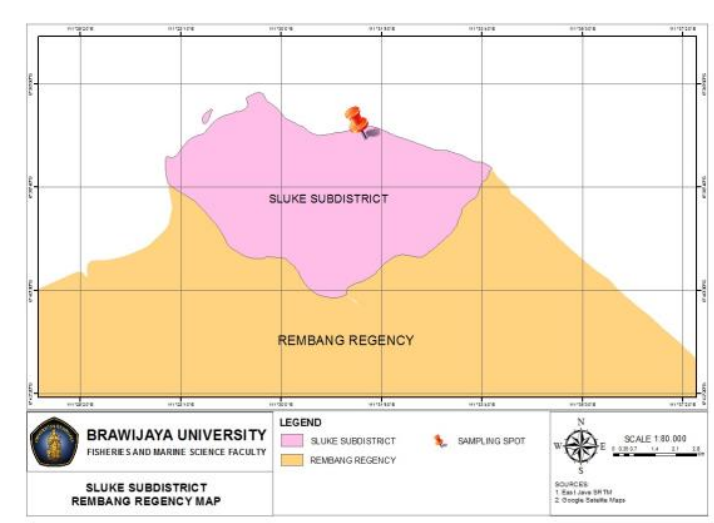

Figure 4. Sluke Subdistrict, Rembang Regency

\section{Data Collection}

This research used survey as the method of collecting the information from blue swimmer crab catchers and collectors representing population group. The sampling was done randomly in various water areas. Blue swimmer crab samples obtained by fisherman who were deposited to the collectors, shown in Table 1.

The tool used in the measurement of carapace wide was calipers with precision of 0.05 $\mathrm{mm}$. Then, the measurement tool of sex ratio is making visual observation or seeing the morphological aspects and secondary sex features. The determination of genital blue swimmer crab can be seen from the color and shape of the abdomen. The calculation of sex was done by comparing the number of samples of male and female caught. The measurement of weight was using an analytical digital scale with precision of $0.01 \mathrm{~g}$, while for measuring gonad weight and gonad observation is an analytical digital scales with accuracy of $0.01 \mathrm{~g}$ (sectio set and magnifying glass).

Table 1. The Sampling of Blue Swimmer Crab

\begin{tabular}{|c|c|c|c|c|}
\hline $\begin{array}{c}\text { Location } \\
\text { (Regency) }\end{array}$ & $\begin{array}{l}\text { Male } \\
\text { (pcs) }\end{array}$ & $\begin{array}{c}\text { Female } \\
\text { (pcs) }\end{array}$ & Total & Sampling \\
\hline Lamongan & 175 & 125 & 300 & \multirow{4}{*}{$\begin{array}{l}\text { wide-range } \\
\text { of carapace } \\
\text { and weight } \\
\text { distribution }\end{array}$} \\
\hline Tuban & 116 & 184 & 300 & \\
\hline Pasuruan & 221 & 79 & 300 & \\
\hline Rembang & 122 & 178 & 300 & \\
\hline Lamongan & 175 & 125 & 300 & \multirow{4}{*}{ sex ratio } \\
\hline Tuban & 116 & 184 & 300 & \\
\hline Pasuruan & 221 & 79 & 300 & \\
\hline Rembang & 122 & 178 & 300 & \\
\hline Lamongan & 175 & 125 & 300 & \multirow{4}{*}{$\begin{array}{c}\text { gonads } \\
\text { maturity } \\
\text { level }\end{array}$} \\
\hline Tuban & 31 & 69 & 100 & \\
\hline Pasuruan & 221 & 79 & 300 & \\
\hline Rembang & 34 & 66 & 100 & \\
\hline
\end{tabular}

The wide of carapace and the distribution of blue swimmer crab weight and the correlation of carapace's wide to individual weights are closely related to the growth rate of the organism. In creating sustainable resources, growth is one of the key factors for determining it. The calculation of carapace wide correlation by weight can be seen from a value of $b$ using the method based on Susanto [11], with formula :

$$
\mathrm{b}=\frac{N \times \Sigma(\log W \times \log L)-(\Sigma \log W \times \log L)}{N \times \Sigma \log ^{2} \mathrm{~L}-(\Sigma L \log L)^{2}}
$$

$$
\log a=(\log W / N)-b x(\log L / N)
$$

Description:

$\mathrm{a}=$ Condition factor

b = Correlation of wide and weight of blue swimmer crab

$\mathrm{W}=$ Blue swimmer crab weight $(\mathrm{g})$

$\mathrm{N}=$ Number of male or female(pcs)

$\mathrm{L}=$ Blue swimmer crab wide $(\mathrm{mm})$

The sex ratio of blue swimmer crab is calculated by comparing a total of male and female using methods based on Zahid and Charles [12], as follows:

$$
\mathbf{X}=\mathbf{J}: \mathbf{B}
$$

Description:

$X=$ Sex ratio

$\mathrm{J}=$ Total of male (pcs)

$B=$ Total of female (pcs)

The gonad maturity level can be done by surgery from body at the abdomen and measured using digital scale with the accuracy of $0.01 \mathrm{~g}$. Otherwise, morphological observations can be seen from color and occupation rate of blue swimmer crab gonad in female hepatic region, which is divided into five levels [13]. At level 1: gonad is immature, white or transparent; level 2: gonad start to mature, yellow/bright orange, not extend into the hapatic region; level 3: gonad in the process of mature, yellow/orange color does not extend/exceed the hepatic area; level 4: mature gonad, yellow/dark orange protruding into the hepatic area; and at level 5: ovigerous, females carry full-fledged eggs (pale eggs to dark yolks) on outside of body/abdomen.

\section{RESULT AND DISCUSSION \\ The Correlation of Carapace Width and Weight of Blue Swimmer Crab}

Each location showed different results. Sample in Lamongan Regency showed that the male blue swimmer crab have larger carapid. This can be due to the growth of female blue swimmer crab will decrease at the time of mature gonad rather than male or also caused by genetic factor of individual them self. The variety sizes of blue swimmer crab obtained can be caused by several factors such as season and depth of waters. The 
correlation of carapace wide to individual weight of blue swimmer crab was done to know the growth pattern and population.

Based on the observations that have been done, the data obtained from total of 300 samples and analyzing the correlation of carapace wide with weight, it shows that the correlation of carapace wide and weight of male and female has a very close correlation, as well as growth pattern, reared allometric negative, because it is $b<3$ (male is $b=0.988$ and female is $b=0.962)$. This is influenced by many factors, especially environment. The genetic factor contributing to the size of male blue swimmer crab reaching maturity at the same size. Generally male blue swimmer crab larger than female [14].

The amount of female blue swimmer crabs are higher than male. Catching location is one of the factors influencing the amount. Most of fisherman do the catching on the deep area in which they catch more female. It is because the female of blue swimmer crab prefer to be in the depth with high salinity for reproduction [15]. The factor of differences in the ratio between males and females are biological factor such as spawning. The female blue swimmer crabs like high salinity waters for spawning, thus spreading to deeper waters than male. Reversely, male blue swimmer crab like low salinity waters that spread in shallow waters [16].

Sample in Tuban Regency, the width of blue swimmer crab have a different pattern size of catch due to the different capture fisheries, where coastal waters of Bancar Subdistrict, Tuban Regency is cloudy so that fisherman catches in deeper waters. The weight distribution pattern of blue swimmer crab body dominated in 89.63-102.76 g class which was suspected due to the catching in shallow waters, where fisherman made the catch to easily set the Bubu (fish trap) by diving into the bottom of waters appropriately.

The correlation between the wide of carapace and weight of captured male blue swimmer crab shows negative allometric of $b<3$ (male is $b=$ 2.532 and female is $b=2.490$ ). Each increase in wide value is followed by an increase in weight value or the other way. The correlation of wide and weight of male blue swimmer crab shows closeness. The acquisition of the width of carapace in correlation with the weight of female blue swimmer crab had shown that the width increased higher than its weight. Besides, the width of carapace and the weight of female blue swimmer crab had close correlation.

The results obtained explain that growth rate of male blue swimmer crab is better than female. In coastal waters of Bancar Subdistrict, Tuban Regency has very few mangrove plants. This is an indication of lack organic material needed by primary organisms which later become bivalve food, gastropod, and mollusca as the main food of male and female blue swimmer crab. The research result said that there are no significant differences in food types during all seasons, regardless of the sexes and sizes. The body size differences do not affect the type of food but affect the amount of food [6].

Sampling in Pasuruan Regency measured the wider carapace on male blue swimmer crab than female. However, the total of male and female blue swimmer crab caught by fisherman has not been in accordance with the Minister of Marine and Fisheries regulations because many blue swimmer crab are caught below-set standards. While the weight of male blue swimmer crab in this study found that male blue swimmer crab is heavier than females. The correlation between the carapace width and body weight of both male and female blue swimmer crab had shown that the carapace width increased faster than the body weight. It indicated that the crabs were captured in small size. The correlation between the wide of carapace and weight of captured male blue swimmer crab shows negative allometric of $b<3$ (male is $b=2.802$ and female is $b=2.771$ ). This has factors such as the availability of feed in nature, genetics, and time of catch, as well as on female used more energy for reproduction so that weight growth is more hampered compared to the wide growth of the carapace. The weight difference between male and female blue swimmer crab suspected due to several factors such as water temperature or influence of growth rate [17].

Sampling in Rembang Regency of blue swimmer crab meet the standards set by No.1/PERMEN-KP/2015, both male and female; although $2 \%$ have wide carapace under the standard to be caught. The catch of blue swimmer crab can be done with size carapace > $10 \mathrm{~cm}$. The blue swimmer crab in the laying state should neither be caught nor be recorded. The result could be dead or in unsuitable size. The correlation of the research, the wide of carapace and weight of captured male blue swimmer crab shows positive allometric is value of $b>3$ (male is $b=3.368$ and female is $b=3.047)$. The 
deployment of caught blue swimmer crab is sometimes on muddy and rocky substrates but more on sandy substrates. In addition, temperature and salinity factors are thought to affect size distribution of blue swimmer crab ( $P$. pelagicus) [16].

The correlation of the wide carapace and weight captured have value of $b=3$. It is isometric growth pattern, a wide growth pattern equal to weight growth. If the value of $b>3$ is positive, allometric growth pattern of weight growth is more dominant than wide growth, and if the value of $b<3$ is negative, allometric growth pattern

A.

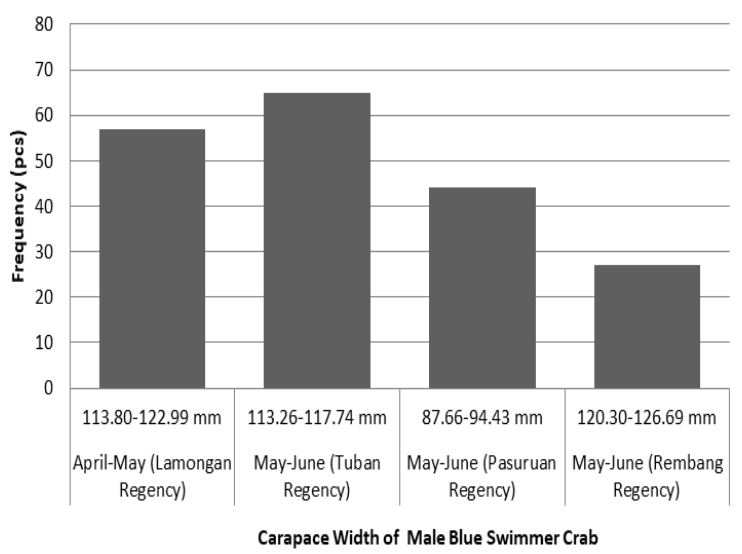

B.

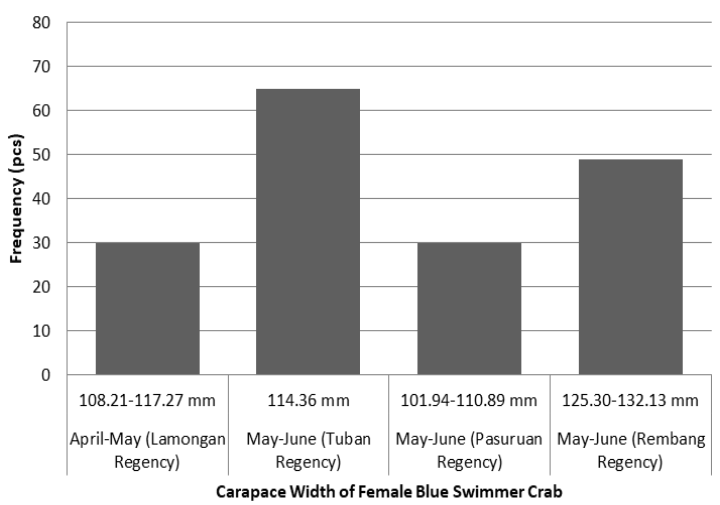

of wide growth is more dominant than weight growth [18]. Deeper waters will result in relatively bigger blue swimmer crab ( $P$. pelagicus) as well as many sandy substrate found. While the results of weight measurement of male are bigger compared to female. This is caused by metabolism in utilizing energy obtained from food. The correlation between wide of carapace and weight is an increase in the value of wide on blue swimmer crab followed by an increase of weight, shown in Figure 5. The results obtained in this study is larger male on blue swimmer crab than female.
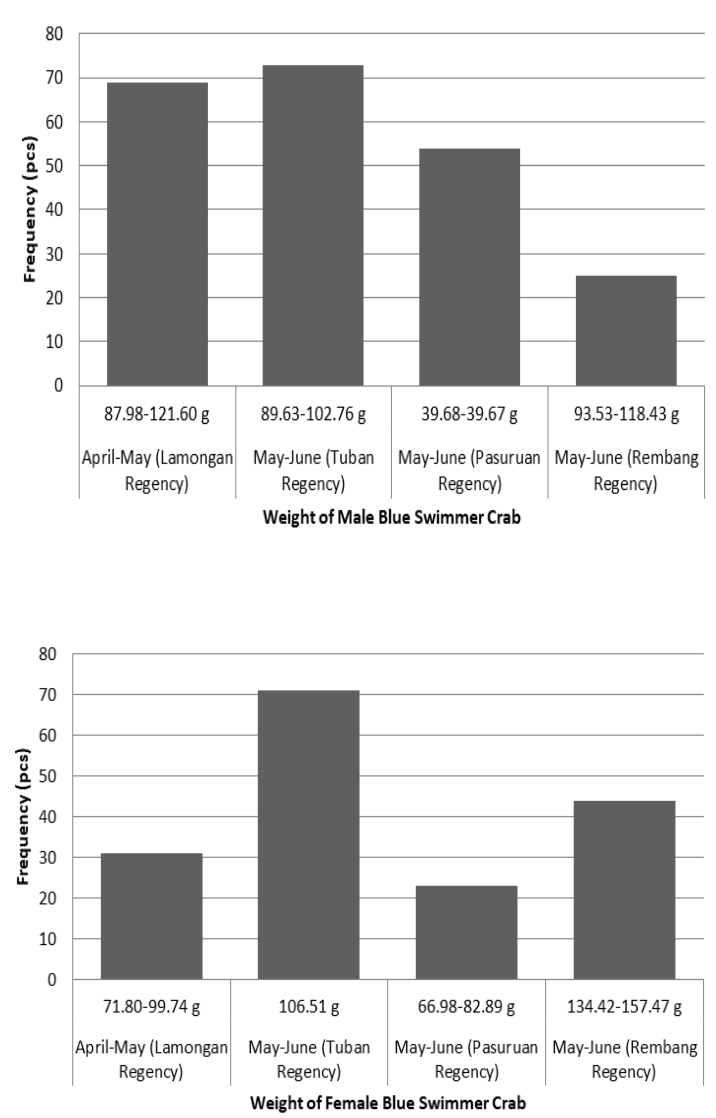

Figure 5. The Sampling of Wide and Weight of Blue Swimmer Crab. A. Wide and Weight of Male Blue Swimmer Crab Sample (P. pelagicus), and B. Wide and Weight of Female Blue Swimmer Crab Sample (P. pelagicus) from collectors.

\section{Sex Ratio}

Sex ratio is the ratio of males and females in the population. The sex ratio in each sampling site showed different results, can be seen in Table 2. The sampling in Lamongan Regency showed the composition of male and female blue swimmer crab are not balanced. The results of this observation indicate that those caught in dominance by male blue swimmer crab, it is probably due to April-May is spawning season for crab. While sampling in Tuban Regency shows male less than female, this is thought to be caused by spawning and fishing season but sampling in Pasuruan showed female is less than male means that composition of crab has an imbalance. The difference is caused by fisherman in an area of caught around the beach or in shallow waters by using a passive fishing trap. Differences in the total of caught are also caused by the male prefer shallow waters while female prefer deeper waters or waters that have high salinity for spawning. 
However, sampling in Rembang Regency shows female is more than male or unbalanced. The factors that affect this sex ratio are influenced by migration and weather changes that may affect a population of blue swimmer crab [16].

Table 2. Distribution of $P$. pelagicus) quantities obtained during study at each time and location of taking from collectors.

\begin{tabular}{ccc}
\hline \multirow{2}{*}{ Time (Location) } & \multicolumn{2}{c}{ Sex Ratio } \\
\cline { 2 - 3 } & Male & Female \\
\hline $\begin{array}{c}\text { April-May } \\
\text { (Lamongan Regency) }\end{array}$ & 1.4 & 1 \\
$\begin{array}{c}\text { May-June } \\
\text { (Tuban Regency) } \\
\quad \text { May-June }\end{array}$ & 1 & 1.5 \\
$\begin{array}{c}\text { (Pasuruan Regency) } \\
\text { May-June }\end{array}$ & 2.8 & 1 \\
(Rembang Regency) & 1 & 1.46 \\
\hline
\end{tabular}

\section{Gonad Maturity Level}

The maturity level of gonads in which gonad develop before and after spawning. The process of development body system gonad will undergo series of morphologic, histological, and cytologic changes. Observations obtained during the study at each time and location of sampling, can be seen in Table 3.

The results of gonad maturity level at each sampling site showed different results. Sampling in Lamongan Regency showed the composition of male and female blue swimmer crab ( $P$. pelagicus) unbalanced in the maturity level of the gonad. It is because in April-May of female spawners began to migrate to the deeper ocean to hatch eggs. While sampling in Tuban Regency shows that highest level of male gonad maturity in a phase of maturity level of the gonad II. This possibility is because it depends on different fishing location in shallow waters so that it is dominated by a young crab that is not yet in a mature phase of the gonad.

Sampling in Pasuruan shows the highest level of female gonad maturity in a phase of maturity level II, possibly because it depends on the environment and caught. Sampling in Rembang Regency, it shows that highest level of gonad maturity in the female with a phase of maturity level of gonads II. It is because the least blue swimmer crabs were caught due to the species with mature gonad went on the deeper water. Blue swimmer crab ( $P$. pelagicus) go to deeper areas to spawning peaks that occurred in July. However, sampling in Pasuruan shows that most gonad maturity level in the female with phase maturity level of gonads II. This is caused by maturity level of gonads I cell is not fully mature and mostly still in the form of egg cells. The maturity level of gonads II egg cells which begin to enter a stage of maturity, the ovari is still small and looks bright yellow. The maturity level of gonads III eggs begin to enter a stage of ovary has pale yellow color, maturity level of gonads IV egg cells have entered maturation phase and ready for fertilizing. The maturity level of gonads $V$ eggs are located on outside of abdomen with pale until yellow color. Male blue swimmer crab like waters with low salinity so that spread more around in a relatively shallow coastal waters [6]. The maturity level of gonads III and IV occur with an indication of adult female blue swimmer crab laying eggs throughout the year. This occurs because reproduction is limited by warm temperatures in subtropical climates. In subtropical climates, female blue swimmer crab postpone development of gonad maturity during the winter season [19].

Table 3. Gonad Maturity Level of Blue Swimmer Crab ( $P$. pelagicus)

\begin{tabular}{ccccc}
\hline \multirow{2}{*}{ Location } & \multicolumn{4}{c}{ The Maturity Level of Gonads Dominant } \\
\cline { 2 - 5 } & $\begin{array}{c}\mathbf{M} \\
\text { (pcs) }\end{array}$ & Freq & $\begin{array}{c}\text { F } \\
\text { (pcs) }\end{array}$ & Freq \\
\hline Lamongan & III & 53 & II \& III & 38 \\
Regency & $\Sigma 175$ & $(30.29 \%)$ & $\Sigma 125$ & $(30.40 \%)$ \\
\hline Tuban & II & 13 & III & 23 \\
Regency & $\Sigma 31$ & $(41.93 \%)$ & $\Sigma 69$ & $(33.33 \%)$ \\
\hline Pasuruan & III & 57 & II & 38 \\
Regency & $\Sigma 221$ & $(25.79 \%)$ & $\Sigma 79$ & $(48.10 \%)$ \\
\hline Rembang & III & 11 & II & 22 \\
Regency & $\Sigma 34$ & $(32.35 \%)$ & $\Sigma 66$ & $(33.33 \%)$ \\
\hline
\end{tabular}

Note: $\mathrm{M}=$ Male, $\mathrm{F}=$ Female, Freq = Frequency,

Pcs = Pieces, $\mathrm{II}$ and III= gonad maturity level

\section{CONCLUSIONS}

The correlation between width of carapace and weight of blue swimmer crab in different areas in Lamongan, Tuban, and Pasuruan have negative allometric growth patterns because they have $b<3$. This suggests that growth of carapace wide is faster than weight. But in Sluke Subdistrict, Rembang Regency, it has positive allometric growth pattern with $b>3$ (male is $b=$ 3.368 and female is $b=3.047$ ).

The sex ratio shows that ratio of males and females is in unbalanced conditions in which females are larger than males. The level of gonad maturity often found in stage II and III, and most rarely found in phase $\mathrm{V}$ so that fishing by fisherman in sampling area is in accordance with No.1/PERMEN-KP/2015, which prohibits the capture of blue swimmer crab in catch conditions 
of gonad maturity level V. The percentage of crab obtained in this study based on an area of capture meet the standards set by No.1/PERMEN-KP/2015.

\section{ACKNOWLEDGEMENT}

The authors would like to thank the researcher, Collectors in Lamongan, Tuban, Pasuruan, Rembang Regency and also Department of Fisheries and Marine Science, University of Brawijaya, Indonesia for their help during this experiment.

\section{REFERENCES}

[1] Kembaren, D.D., E. Tri, Suprapto. 2012. Biologi dan parameter populasi rajungan (Portunus pelagicus) di perairan bone dan sekitarnya. Biology and Population Dynamics. Research Institute for Marine Fisheries. Jakarta.

[2] Ministry of Marine Affairs and Fisheries. 2012. Statistik perikanan tangkap indonesia tahun 2011. (ID): Directorate General of Capture Fisheries, Ministry of Marine Affairs and Fisheries. Jakarta.

[3] Svane, I., G.E Hooper. 2004. Blue swimmer crab (Portunus pelagicus) fishery. Fishery assessment report to PIRSA for the blue crab fishery management committee. South Australian Research and Development Institute (Aquatic Sciences). Adelaide. RD03/0274-2.

[4] Arshad, A., M.S. Efrizal, Kamarudin, C.R. Saad. 2006. Study on fecundity, embryology and larva development of blue swimming crab Portunus pelagicus (Linnaeus, 1758) under laboratory conditions. J. Fish. Hydrobiol. 1(1). 35-44.

[5] Kangas, M.I. 2000. Synopsis of the biology and exploitation of the blue swimmer crab; Portunus pelagicus Linnaeus, in Western Australia. J. Fish. Res. Western Australia. 12(1). 1-22.

[6] Chande, A.I., Y.D Mgaya. 2004. Food habits of the blue swimming crab Portunus pelagicus along the coast of Dar Es Salaam, Tanzania. Western Indian Ocean J. Mar. Sci. 3(1). 37-42.

[7] Josileen, J. 2011. Food and feeding of the blue swimmer crab, Portunus pelagicus (Linnaeus, 1758) (Decapoda, Brachyura) along the coast of Mandapam, Tamil Nadu, India. Crustaceana. 84(10). 1169-1180.

[8] Lovett, D.L. 1981. A guide to shirmps, prawns, lobster and crab of Malaysia and Singapore. Faculty of Fisheries and Marine
Science, Universiti Pertanian Malaysia. Serdang, Selangor.

[9] Juwana, S., K. Romimohtarto. 2000. Rajungan: perikanan, cara budidaya dan menu masakan. Djambatan. Jakarta.

[10] Wulandari, W., R. Herry, B. Asriyanto. 2014. Analisis perbedaan kedalaman dan substrat dasar terhadap hasil tangkapan rajungan (Swimming Crab) dengan arad rajungan di perairan Wedung, Demak. J. Fish. Resour. Util. Manage. Technol. 3(4). 85-93.

[11] Susanto, A. 2011. Analisa beberapa aspek reproduksi kepiting bakau (Scylla serata) di perairan segara anakan, Kabupaten Cilacap, Jawa Tengah. Jurnal Matematika Sains dan Teknologi. 12(1). 30-36.

[12] Zahid, A., P.H.S Charles. 2009. Biologi reproduksi dan faktor kondisi Ikan llat-ilat Cynoglossis bilineatus (Lac.1820) (Pisces: Cynoglossidae) di perairan Pantai Mayangan Jawa Barat. J. Indonesian Anthropol. 9(1). 85-95.

[13] Sumpton, W.D., M.A. Potter, G.S Smith. 1994. Reproductions and growth of the commercial sand crab (Portunus pelagicus) in Moreton Bay Queensland. Asian Fish. Sci. 7. 103-133.

[14] Warner, G.F. 1977. The biology of crabs. Elek Science. London.

[15] Sunarto, D. Soedharma, E. Riani, S. Martasuganda. 2010. Performa pertumbuhan dan reproduksi Rajungan (Portunus pelagicus) di Perairan Pantai Kabupaten Brebes. OmniAkuatika. 9(11). 75-82.

[16] Mehdi, H., V. Amir, P. Yaghob, M. Ali. 2012. Sex ratio, size distribution and seasonal abundance of blue swimming crab, Portunus pelagicus (Linnaeus, 1758) in Persian Gulf Coasts, Iran. World Appl. Sci. J. 17(7). 919925.

[17] Lee, H.H., C.C. Hsu. 2003. Population biology of the swimming crab Portunus sanguinolentus in the waters off Northern Taiwan. J. Crustacean Biol. 23(3). 691-699.

[18] Effendie, M.I. 2002. Biologi perikanan. Yayasan Pustaka Nusantara. Yogyakarta.

[19] Kamrani, E., Sabili, N. Abdul, M. Yahyavi. 2010. Stock assessment and reproductive biology of the blue swimming crab, Portunus pelagicus in Bandar Abbas Coastal Waters, Northern Persian Gulf. J. Persian Gulf (Mar. Sci.). 1(2). 11-22. 